Studia Judaica 22 (2019), nr 2 (44), s. 213-233

doi:10.4467/24500100STJ.19.010.12393

Małgorzata Domagalska (iD) https://orcid.org/0000-0002-7104-134X

\title{
„Wielką jest semicka moc”. Poetyckie strofy w „Roli” Jana Jeleńskiego
}

“HOW ENORMOUS IS SEMITIC POWER”: POETRY IN JAN JELEŃSKI'S ROLA

\begin{abstract}
Rola was the first antisemitic weekly in Poland published in Warsaw between 1883 and 1912. According to the nineteenth-century custom, not only journalism, but also novels published in weekly installments, as well as poems were included in the magazine. In poetry, lofty or religious topics were raised at the time of Christmas or Easter, or virulent antisemitic satire was published on various occasions. The antisemitic satire corresponded to the themes taken up in prose and journalism. The themes were dominated by the myth of Judeopolonia, issues of assimilation and social advancement of Jews, attacks on mixed marriages and mockery of Zionism, or the colonies established by Baron Hirsch in Argentina. It can be said that both prose and poetry were servile to journalism and strengthened the antisemitic content dominant in the weekly.
\end{abstract}

Keywords: antisemitic poetry, Rola, Jan Jeleński, antisemitism.

Słowa kluczowe: poezja antysemicka, „Rola”, Jan Jeleński, antysemityzm.

Tygodnik „Rola” ukazywał się w latach 1883-1912 w Warszawie, do roku 1909 pod redakcją Jana Jeleńskiego, później - jego syna Szczepana. Był pierwszym programowo antysemickim periodykiem, w którym podstawowym zagadnieniem, powiązanym ze wszelkimi aspektami życia społecznego, politycznego, a nawet prywatnego, była kwestia żydowska ${ }^{1}$. Wśród

${ }^{1}$ Więcej na temat „Roli” w: Grzegorz Krzywiec, Polska bez Żydów. Studia z dziejów idei, wyobrażen i praktyk antysemickich na ziemiach polskich poczatku XX wieku (1905-1914), Warszawa 2017; Maciej Moszyński, Antysemityzm w Królestwie Polskim. Narodziny nowoczesnej ideologii antyżydowskiej (1864-1914), Poznań 2017. 
niemalże 130 jego współpracowników wymienianych w Ćwierćwieczu walki - pamiątkowej księdze „Roli”", prawą ręką redaktora naczelnego był Teodor Jeske-Choiński, który po śmierci swojego mentora, doceniając jego zasługi położone na tym polu, w broszurze zatytułowanej Poznaj Żyda pisał:

Ostatnie pięćdziesięciolecie wydało w Polsce tylko dwóch zdeklarowanych antysemitów: Jana Jeleńskiego i Teodora Jeske-Choińskiego (od r. 1882). Pierwszy, utalentowany publicysta, był typem antysemity ,instynktowego”. Odczuwał on doskonale Żyda, widział jego szkodliwość społeczną i ekonomiczną, na którą zwracał głównie uwagę. On to, praktyczny, trzeźwy, jest twórcą sklepów chrześcijańskich - ojcem naszego dzisiejszego ruchu spółdzielczego, za co należy mu się trwała, wdzięczna pamięć narodu. - Drugi dopełniał pierwszego jako teoretyk kierunku³.

„Współtowarzysze boju”, jak: Ludomir Prószyński - „szczery chrześcijanin i antysemita z głębokiego przekonania"4; Gustaw Czernicki, który „wykwintnym piórem swoim przyswoił literaturze naszej Żydowska Francję Édouarda Drumonta”5; Teofil Merunowicz i Józef Rogosz, czyli „pionierzy ruchu antysemickiego w Galicji”"; Antoni Skrzynecki, autor wielu artykułów i powieści; ksiądz Justyn Bonawentura Pranajtis, znany ze swego cenionego w „Roli” dzieła Christianus in Talmude Judaeorum ${ }^{7}$; czy wreszcie „dostojny Pasterz”, biskup Karol Niedziałkowski, a także wielu innych, czynnie wspierali Jeleńskiego płodami swego pióra korespondującymi z linią programową pisma9.

Szpalty „Roli” wypełniała nie tylko publicystyka, skupiona obsesyjnie wokół kwestii żydowskiej, lecz także beletrystyka. Mająca aspiracje

2 Zob. Ćwierćwiecze walki. Księga pamiątkowa „Roli”, Warszawa 1910.

3 Teodor Jeske-Choiński, Poznaj Żyda, wyd. 3, Warszawa 1912, s. 200. Więcej na temat poglądów Teodora Jeske-Choińskiego zob.: Theodore R. Weeks, The "International Jewish Conspiracy” Reaches Poland: Teodor Jeske-Choinski and His Works, „East European Quarterly" 31 (1997), nr 1, s. 21-41; Michał Śliwa, Ksenofobie antyżydowskie Teodora Jeske-Choińskiego, [w:] tenże, Obcy czy swoi. Z dziejów poglądów na kwestię żydowska w Polsce w XIX i XX wieku, Kraków 1997, s. 84-95.

${ }^{4}$ Kronika bieżaca, „Rola” (1901), nr 31, s. 488.

${ }^{5}$ Drukowanie streszczonego dzieła Drumonta pod tytułem Francja zżydziała. Studium $z$ historii wspótczesnej rozpoczęło się w „Roli” już w 1886 r., tuż po opublikowaniu książki w ojczyźnie autora. Więcej na ten temat: Agnieszka Friedrich, Recepcja antysemityzmu francuskiego w „Roli” Jana Jeleńskiego, [w:] Żydzi i judaizm we współczesnych badaniach polskich, t. 6, red. Stefan Gąsiorowski, Magdalena Ruta, Kraków 2017, s. 167-181.

${ }_{6}^{6}$ Ćwierćwiecze walki..., s. 97.

${ }^{7}$ Dzieło księdza Justyna Pranajtisa, profesora Akademii Duchownej w Petersburgu, opublikowano w języku łacińskim w roku 1892, po polsku zaś ukazało się w dwudziestoleciu międzywojennym pod tytułem Chrześcijanin w Talmudzie żydowskim.

${ }^{8}$ Ćwierćwiecze walki..., s. 94.

9 Wszyscy „współtowarzysze boju” wymienieni zostali w Ćwierćwieczu walki w rozdziale o takim tytule (s. 94-104). 
kulturalne „Rola” początkowo zamieszczała głównie krótkie opowiadania opatrzone znaczącymi tytułami, odzwierciedlającymi nie tylko myśli przewodnie fabuł publikowanych tekstów, ale także dominujące tematy w antyżydowskiej publicystyce. Problematyka asymilacji, jak również kreowana wizja supremacji żydowskiej wraz z utrwalaniem antysemickiego stereotypu wysuwały się tu na plan pierwszy. Tytuły zazwyczaj anonimowo publikowanych utworów, np.: Z karczmy do pałacu, Filozofia pana Miliona, Gdyby nie Aron, Czy to we krwi plynie, Monolog i sen Dawida w noc sylwestrowa, wyznaczały u zarania leitmotiv rolarskiej twórczości ${ }^{10}$.

Antyżydowską publicystykę w „Roli”, a także drukowane na jej łamach opowiadania i powieści poddano już badawczemu oglądowi. Badacze wskazali ideologiczne założenia i dominanty tematyczne tekstów, które wypełniały szpalty tygodnika przez trzydzieści lat jego istnienia. Dokonano również oceny rolarskiego antysemityzmu i jego wpływu na rozwój uprzedzeń antysemickich na przełomie wieku XIX i XX ${ }^{11}$. Choć mowa wiązana w piśmie Jeleńskiego nie była formą uprzywilejowaną, z czasem znalazła w nim swoje miejsce, gdy „Rola” określiła już ideowy profil i umocniła pozycję na warszawskim rynku prasy. Warto więc przyjrzeć się, czemu służyła, jaką przybierała postać, i treściom, które ze sobą niosła. Czy była tylko literackim dodatkiem w piśmie, czy też w sposób przemyślany stała się jednym ze sposobów walki z „wewnętrznym wrogiem” - Żydem.

\section{Szlachcic - ale postępowy?}

W inicjalnej fazie na łamach „Roli” brakło miejsca dla poezji. Zapewne publicystyka i podporządkowana tendencji proza lepiej służyły misji pisma wyrażonej w programowym artykule Czego chcemy ${ }^{12}$. Podstawowym celem tygodnika miała być walka z ,żywiołem" niemieckim i żydowskim, a mowa wiązana w swej skrótowej formie nie mogła w pełni wyrazić konstytuujących się ideologicznych postulatów. W 1883 r. nie zamieszczono w piśmie ani jednego wiersza, jednakże publikowano głosy krytyczne i omówienia tomików poetyckich lub analizowano aspekty współczesnej poezji na

${ }^{10}$ Więcej na ten temat w: Małgorzata Domagalska, Zatrute ziarno. Proza antysemicka na tamach „Roli” (1883-1912), Warszawa 2015, s. 123-307.

${ }^{11}$ Najważniejsze prace dotyczące „Roli” autorstwa Małgorzaty Domagalskiej, Agnieszki Friedrich, Grzegorza Krzywca, Macieja Moszyńskiego, Theodore’a R. Weeksa zostały przywołane w tym artykule.

${ }^{12}$ Czego chcemy?, „Rola” (1883), nr 1, s. 1. 
przykład w cyklu artykułów Teodora Jeske-Choińskiego Ideały beletrystyki pozytywnej ${ }^{13}$. Nieco później proste utwory wierszowane, jakoby nadsyłane przez czytelników, wplecione były w felietony Jeleńskiego Na posterunku. Funkcjonowały one jako komentarz do aktualnych kwestii, którymi zainteresowany był autor. W 27. numerze z $1886 \mathrm{r}$. wiersz podpisany przez "Szlachcica - ale postępowego" pojawił się w felietonie atakującym Komitet Giełdowy ${ }^{14}$. Jeleński, żywo zaangażowany w batalię przeciwko Memoriałowi przygotowanemu przez Jana Blocha i Henryka Natansona, prezesów warszawskiej giełdy, dawał w nim asumpt nie tylko do rozprawy z pismami zachowawczymi - „Niwą” i „Wiekiem” - które oskarżał o brak zdecydowanego stanowiska w kwestii żydowskiej, ale także do częstego na łamach „Roli” ataku na postępowców ${ }^{15}$. Uderzał przy tym w zwolenników zbliżenia polsko-żydowskiego i asymilacji, będących podstawowym celem ataków „Roli” do początków XX w., gdy na arenie pojawili się też inni wrogowie, którym także przypisywano żydowskie pochodzenie i destrukcyjne intencje: feministki czy socjaliści. Utwór zawierał również pozorną krytykę szlachty, której środowiska pozytywistyczne często zarzucały anachroniczny model życia, nieprzystający do społeczno-ekonomicznych warunków schyłku XIX w. W optyce rolarzy szlachta, choć niewolna od wad, była jednak ostoją wartości, takich jak honor czy cnota, rzekomo obcych Żydom, i miała być gwarantem hermetyzmu społecznego. Ponadto Jeleński rozprawiał się ze sprzedajnym, jego zdaniem, światem literackim i ironicznie dawał zalecenia literatom, aby mieli na uwadze przede

13 Teodor Jeske-Choiński, Ideały beletrystyki pozytywnej, „Rola” (1887), nr 6-48 (w numerze 43 czasopisma Jeske-Choiński skupia się na poezji Adama Asnyka, w numerach 46-47 na twórczości Marii Konopnickiej).

${ }^{14}$ Felieton dotyczył Memoriału Komitetu Giełdowego przygotowanego przez prezesa i wiceprezesa warszawskiej Giełdy - Jana Blocha oraz Henryka Natansona - w którym przeciwstawiano się wprowadzeniu restrykcji majowych z 1882 r. na terenach polskich. Autorzy memoriału w raporcie wskazywali korzyści ekonomiczne dla gospodarki Królestwa Polskiego wynikające z równouprawnienia Żydów oraz szkody, które mogą powstać z wprowadzenia ograniczeń. Poufny dokument przedostał się do prasy, a przedrukowany we fragmentach w „Niwie” stał się powodem oskarżenia środowisk żydowskich o arogancję, nieuprawnione przypisywanie sobie zasług przy jednoczesnej deprecjacji społeczeństwa polskiego, ukazywanego jako zacofane i niezdolne do działalności na rzecz ekonomicznego rozwoju kraju. W rzeczywistości dokument nie był jednoznaczny i wskazywał także istotne problemy istniejące w środowiskach żydowskich. Więcej na ten temat: Artur Eisenbach, Memoriat w sprawie sytuacji Żydów w Królestwie Polskim, „Biuletyn Historii Żydów Polskich" (1976), nr 4, s. 35-62; Theodore R. Weeks, The Stock Exchange Memorandum Controversy of 1885-1886, [w:] tenże, From Assimilation to Antisemitism: The "Jewish Question" in Poland 1850-1914, DeKalb 2006, s. 96-99.

${ }_{15}$ Więcej na ten temat: Maciej Moszyński, Od „duchowego powinowactwa” do bezwzględnej walki z antysemitami, [w:] tenże, Antysemityzm w Królestwie Polskim ..., s. 254-273. 
wszystkim żydowskich wydawców i ich publiczność ze względu na materialne profity. Tym samym podkreślał swoją bezkompromisowość i niezależność w głoszeniu opinii - w przeciwieństwie do innych krytykowanych publicystów i pisarzy, jakoby uzależnionych od żydowskich wydawców. W apostroficznym zwrocie upominał pracowników pióra:

Literacie! Literatko!

Powieść piszesz? Pomnij sobie:

Bohaterką piękną, gładką

Sura, Chaja jest w tej dobie!

Żyd - co prawda - kat z Golgoty,

Ale postęp plwa na waśnie!

Chrystus?... Furda!

Cielec złoty, To-Bóg!

Mistrz tak uczy właśnie.

Więc niech żyją Icki, Jojny,

Bo to naród postępowy,

Możny, sprytny i dostojny...

Goje, schylcie przed nim głowy! ${ }^{16}$.

W kolejnym utworze ostrze satyry Jeleński skierował na wielokrotnie atakowanego w „Roli” Adama Wiślickiego, oskarżanego o szerzenie ateizmu na łamach redagowanego przezeń „Przeglądu Tygodniowego”, organu polskich pozytywistów ${ }^{17}$. Redaktor „Roli” określał w ten sposób własne miejsce, bliższe konserwatystom, jednak nietożsame z nimi ze względu na radykalne postrzeganie kwestii żydowskiej ${ }^{18}$. Podobnie do nich Kamienny, bo tak Jeleński podpisywał swoje cotygodniowe felietony Na posterunku, sytuował się w gronie obrońców wiary i tradycji - ostoi polskości, a w ujęciu „Roli” także zapory przeciwko rosnącym wpływom żydowskim, wzmacnianym m.in. przez tygodnik Wiślickiego:

Niechaj żyje Synagoga!

Bóg z Golgoty?... Wymysł gładki

Klechów! Nie ma, nie ma Boga!

Skaczcie z wrogiem Jego, dziatki!

${ }^{16}$ Kamienny, Na posterunku, „Rola” (1886), nr 27, s. 320.

${ }^{17}$ Kamienny, Na posterunku, „Rola” (1886), nr 32, s. 372.

18 Por. Marek Pąkciński, Publikacje „młodych konserwatystów” na tamach „Stowa” $i$,Roli”, [w:] tenże, Konserwatyzm na rozdrożu. „Młodzi konserwatyści” warszawscy wobec ideowych dylematów schytku XIX wieku, Warszawa 1994, s. 129-147. 
Tak! Precz z Krzyżem i z Kościołem!

Boga nie ma! Kościół kłamie!

Krzycz, nasz synku, z żydkiem społem:

Żyj, z Wiślicy nasz, Adamie! ${ }^{19}$.

W wierszu „Szlachcica - ale postępowego”, czyli najprawdopodobniej samego Jeleńskiego, jak w soczewce skupiają się wątki obecne w „Roli”: połączenie tradycyjnego antyjudaizmu, oskarżającego Żydów o zabójstwo Chrystusa, z atakiem na polskich sprzedawczyków, którzy dla mamony gotowi zaprzeć się prawdziwej wiary. Pojawia się też stały wątek Judeo-Polonii i dominacji żydowskiej, często występujący w rolarskiej prozie.

W innym utworze wplecionym w cotygodniowy felieton - nie bez powodu podpisanym „Jedna z matek” - do przewin żydowskich dołączone jest też szerzenie bezwstydu, rozpasania, pornografii ${ }^{20}$. W tym procederze sekundują Żydom naturaliści, a także tygodnik „Świt”, wydawany przez Salomona Lewentala i redagowany przez kobietę, co jest dodatkowym powodem potępienia. Jeleński nie wymienia jednak jej nazwiska, jakby chciał tym razem zakamuflować atak. Być może powodem jest fakt, że poprzednią redaktorką „Świtu” była ceniona także w „Roli” Maria Konopnicka. Jej następczynią została Waleria Marrené zaangażowana w krytykowany w piśmie Jeleńskiego ruch emancypacji kobiet ${ }^{21}$. Pytanie postawione w pierwszej strofie w zasadzie jest jedynie retoryczne:

Któż tak cnotę brudzi, hydzi,

Na pociechę zdrożną czarta?

Kto? Serdeczni nasi, żydzi!

Czerń z sumienia, z czci odarta ${ }^{22}$.

W poetyckich rymach Jeleński skupiał się także na jednym z ulubionych obiektów ataku, czyli na Samuelu Peltynie, redaktorze „Izraelity”, nazywanym przez niego zazwyczaj „,panem Jojną od Izraelity”, , uspołecznionym już obywatelem i polakiem mojżeszowym”, oczywiście w pejoratywnym znaczeniu ${ }^{23}$. „Polak mojżeszowy” był zresztą w pojęciu Jeleńskiego

${ }^{19}$ Kamienny, Na posterunku, „Rola” (1886), nr 33, s. 392.

${ }^{20}$ Kamienny, Na posterunku, „Rola” (1886), nr 36, s. 427. Waleria Marrené obejmuje redakcje „Świtu” 6 kwietnia; numer „Roli” z atakującym „Świt” wierszem datowany jest na 23 sierpnia $1886 \mathrm{r}$.

${ }^{21}$ Więcej na temat „Świtu” zob.: Maria Zawialska, „Świt” Marii Konopnickiej. Zarys monograficzny tygodnika dla kobiet, Wrocław 1978.

${ }_{22}$ Kamienny, Na posterunku, „Rola” (1886), nr 36, s. 427.

${ }_{23}$ Zob. m.in.: Kamienny, Na posterunku, „Rola” (1886), nr 46, s. 547; także: „Rola” (1888), nr 11, s. 127. 
oksymoronem. Redaktor „Roli” przypisywał więc Peltynowi piosenkę nazwaną Przegladem politycznym i śpiewaną w rytmie krakowiaka. Treść była adekwatna do postrzegania integracjonistów jako ludzi mających na względzie jedynie własne „geszefty”, w globalnej zresztą skali:

Niech Włoch w Abisynii

Co chce sobie czyni.

Niech Anglik w Afganie

Nawet na łbie stanie.

[...]

Oni z armatami

Niech śmierć sobie niosą.

My im lepiej strzelim

Baissą albo haussą.

Ich krwią w razie wojny

Pole się zrumieni.

A nam zawsze zyski

Kapną do kieszeni ${ }^{24}$.

Jeleński odwołuje się tutaj do negatywnego stereotypu, często widocznego zarówno w publicystyce, jak i powieściach antysemickich, ukazującego Żydów jako manipulatorów i spekulantów zbijających kapitał dzięki wojnie. Nawiązuje ponadto do utrwalonego w antysemickim imaginarium wizerunku Żyda unikającego wojska czy niezdolnego do służby ${ }^{25}$. W tekście obecny jest ponadto lęk przed gospodarką kapitałową traktowaną jako zło i narzędzie w rękach Żydów do wykorzystywania naiwnych już nie tylko Polaków, ale i Europejczyków ${ }^{26}$.

${ }^{24}$ Kamienny, Na posterunku, „Rola” (1888), nr 5, s. 56. Zdaniem Zuzanny Kołodziejskiej - dla integracjonistów, najbardziej związanych z kulturą polską, ataki Jeleńskiego były bolesne. Zob. Zuzanna Kołodziejska, „Izraelita” (1866-1915). Znaczenie kulturowe i literackie czasopisma, Kraków 2014, s. 126.

${ }_{25}$ Jak zauważa Maria Janion: „Wojskowe cechy postawy i postępowania uważano powszechnie za całkowicie obce Izraelitom, ich »naturze « ostrożnej i tchórzliwej, bojaźliwej i lękliwej, ich »skłonności« do rzucania się do ucieczki i ukrywania się w jakichkolwiek trudniejszych sytuacjach, ich »wrodzonej« niechęci do żołnierskiego rzemiosła, ich kosmopolityzmowi i egoizmowi, objawiającym się w braku przywiązania do jakiejkolwiek ojczyzny i niemożności poświęcenia się za »sprawę«. Żyd z istoty swej niejako predestynowany był na szpiega i zdrajcę". Maria Janion, Pułkownik żydowski, [w:] taż, Bohater, spisek, śmierć. Wyktady żydowskie, Warszawa 2009, s. 13.

${ }^{26}$ Oskarżenia o sterowanie falami hossy i bessy widoczne są w wielu utworach prozatorskich publikowanych w „Roli”, m.in. w opowiadaniach: P..., Wielki człowiek. Ilustracja do gospodarki finansistów niemieckich, „Rola” (1884), nr 11-32; Antoni Werytus [Antoni Skrzynecki], Warszawa w 2000 roku. Opowieść z notat, „Rola” (1900), nr 50 - (1902), nr 6; 


\section{Obrazki giełdowe}

Niepokoje i lęki związane z rozwijającym się rynkiem akcji widoczne są także w Obrazkach giełdowych publikowanych cyklicznie od roku 1895, zawierających karykaturalne opisy maklerów giełdowych, oczywiście Żydów. Aby nie było żadnych wątpliwości co do etnicznego pochodzenia, bohaterowie tych utworów posługują się specyficzną, zniekształconą polszczyzną, a ich wyobrażone ciała naznaczone są cechami implikującymi żydowskość i odrażający charakter. W opisie dominuje generalizacja i pogarda opierająca się na deprecjonowaniu pochodzenia, wzmocniona aluzjami do postaci o negatywnym spektrum odniesień kulturowych. Oto przykład:

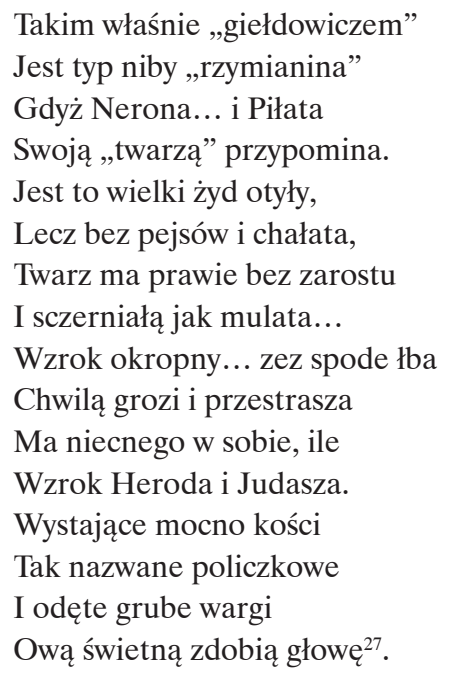

Paweł Kośmiński, ukrywający się pod pseudonimem Nie-Judofil, manipuluje ponadto uczuciami odbiorcy, z jednej strony kładąc na szali łzy ciężko pracujących ludzi, którzy chcą naiwnie powiększyć swoje skromne kapitały, z drugiej - rekinów giełdowych, oczywiście Żydów, pozbawionych czci i sumienia ${ }^{28}$. Te same wątki pojawiają się również w prozie eksponującej

Jan Mieroszewicz [Wacław Gąsiorowski], Zginęła głupota! Powieść z niedalekiej przyszłości, „Rola” (1899), nr 1-38.

${ }^{27}$ Nie-Judofil [Paweł Kośmiński], Obrazki giełdowe, „Rola” (1896), nr 15, s. 244. W roku śmierci Pawła Kośmińskiego (1860-1896) ukazał się tom jego poezji o zupełnie innym, refleksyjnym, osobistym, często elegijnym, funeralnym charakterze. Działalności w „Roli”, uprawianej głównie pod pseudonimem Nie-Judofil, nie odnotowuje biogram zamieszczony w Polskim Słowniku Biograficznym. Por. Stanisław Sierotwiński, Kośmiński Pawet, [w:] Polski Stownik Biograficzny, t. 14, Wrocław 1968, s. 442-444.

${ }^{28}$ Nie-Judofil, Obrazki giełdowe, „Rola” (1895), nr 8, s. 119; nr 14, s. 224. 
naiwność chcących pomnożyć skromny dorobek swego życia polskich bohaterów i pazerność bankierów pozbawionych ludzkich uczuć. W obu rodzajach twórczości skumulowane są lęki związane z gospodarką kapitałową, obrotem akcjami, czyli przeciwieństwem preferowanej w „Roli” bezpośredniej wymiany towarów i usług. Weksle i akcje były zresztą uznawane w „Roli” za wynalazek Żydów i złoty środek służący ich bogaceniu się, stąd też jednym z propagowanych w „Roli” rozwiązań było zakładanie włościańskich kas zapomogowych czy chrześcijańskich sklepów.

\section{Nasze „kliki”}

Zarówno Obrazki giełdowe, jak i zamieszczony w 1890 r. wiersz Metamorfozy nowoczesne wpisują się w cykl pamfletów Podskarbiowie narodu, które „Rola” zaczęła drukować w tym samym roku. W Podskarbich narodu celem ataku byli prominentni przedstawiciele burżuazji warszawskiej, jak Leon Władysław Loewenstein - skoligacony z rodziną Kronenbergów przemysłowiec i współwłaściciel zakładów „Lilpop, Rau i Loewenstein”, baron Leopold Julian Kronenberg, rodzina Natansonów czy Jan Gotlieb Bloch - bankier i przemysłowiec, potentat kolejowy i prezes Komitetu Giełdowego. To on najprawdopodobniej jest bohaterem Metamorfoz, których autor ukrywa się pod pseudonimem Novus. Przedmiotem wiersza jest biografia bohatera zgodna z przyjętym także w Podskarbich schematem mającym na celu całkowitą deprecjację atakowanego. Mechanizm ośmieszenia polega na przypisywaniu bohaterom wstydliwej i ukrywanej przeszłości - początków kariery w karczmie i zgodnego z antysemickim stereotypem dorabiania się na rozpijaniu chłopów, aż po budowę pałacu w Warszawie i kupno utytułowanego zięcia. W tym przypadku byłaby tu widoczna aluzja do Józefa Weysenhoffa, pisarza, męża córki Blocha, Aleksandry Emilii:

Dwojga imion Jan Bogumił -

Dziedzic Dudków, baron Gdański,

Pół Warszawy zjednał, zdumił,

Blichtrem buty wielkopańskiej.

Kupił pałac, kupił zięcia,

I z nazwiskiem i z koroną,

I już czeka wnuka księcia

Z sępio wschodnim nosem pono ${ }^{29}$.

${ }^{29}$ Novus, Metamorfozy nowoczesne, „Rola” (1890), nr 26, s. 445. W Podskarbich narodu Jan Gotlieb Bloch prezentowany jest jako Jakub Gottfried Kolb w: „Rola” (1891), nr 13-15. 
Utworem zbudowanym na podobnym fabularnym schemacie jest także wiersz Kośmińskiego Żywot zacnego człowieka (Portret z natury) ${ }^{30}$. Również w tym przypadku biografia bohatera wpisuje się w ścieżkę kariery wiodącą z karczmy do pałacu. Droga do bogactwa prowadzi też poprzez wypłatę asekuracji po pożarze karczmy podpalonej przez jej właściciela. Wierszowana biografia Icka Kindebubego kończy się na jego śmierci i pogrzebie, uświetnionym mową wygłoszoną przez znanego literata, w której podkreślone są zasługi zmarłego jako szanowanego obywatela i filantropa. Tym samym Kośmiński dołącza do chóru rolarzy potępiających sprzedajnych literatów. Podobną funkcję pełni także cykl pisanych pod pseudonimem, wierszowanych pamfletów publikowanych w roku 1891 pt. Nasze „kliki” (Galeria sylwetek, grup i jednostek), uderzający w środowisko literatów warszawskich ${ }^{31}$. Atak wymierzony jest nie tylko w redakcje potępianych czasopism, ale - zgodnie z przyjętą w „Roli” optyką - w publicystów pochodzenia żydowskiego, m.in. w Cezarego Jellentę, krytyka literackiego, powieściopisarza i poetę pisującego w „Przeglądzie Tygodniowym”.

Wątki wiążące się z problematyką asymilacji, a przede wszystkim integracji Żydów i Polaków, będące właściwie leitmotivem rolarskiej prozy i publicystyki, pojawiają się w tygodniku już wcześniej. Utwór z 1887 r., włączony przez Jeleńskiego do jego felietonu, można uznać za preludium do Podskarbich narodu. Ogniskuje on kwestie żywo obchodzące redaktora naczelnego, dla którego proces akulturacji oraz zmiana statusu społecznego i politycznego Żydów w zaborze rosyjskim po uzyskanym przez nich w $1862 \mathrm{r}$. równouprawnieniu były nie do przyjęcia ${ }^{32}$. O ile świat kasty był przez niego akceptowalny, o tyle przekraczanie kulturowych granic i integracja $\mathrm{z}$ Polakami na prawach równości stały się głównym motorem jego antyżydowskiej publicystyki. Nic więc dziwnego, że w wierszu wplecionym w cotygodniowy felieton pojawiła się refleksja:

Niegdyś dziad

czosnek jadł,

Zob. także: Agnieszka Friedrich, The Image of a Wealthy Jewish Family in the Anti-semitic Polish Weekly “Rola”, „Scripta Judaica Cracoviensia” (2015), nr 13, s. 81-92.

${ }^{30}$ Paweł Kośmiński, Żywot zacnego człowieka (Portret z natury), „Rola” (1890), nr 38, s. 663.

${ }^{31}$ Nescio, Nasze „kliki” (Galeria sylwetek, grup i jednostek), „Rola” (1891), nr 23, s. 388389; nr 26, s. 440-441; nr 30, s. 508-509; nr 39, s. 660-662.

${ }^{32}$ Zob. Artur Eisenbach, Emancypacja Żydów na ziemiach polskich 1785-1870 na tle europejskim, Warszawa 1988, s. 481. 


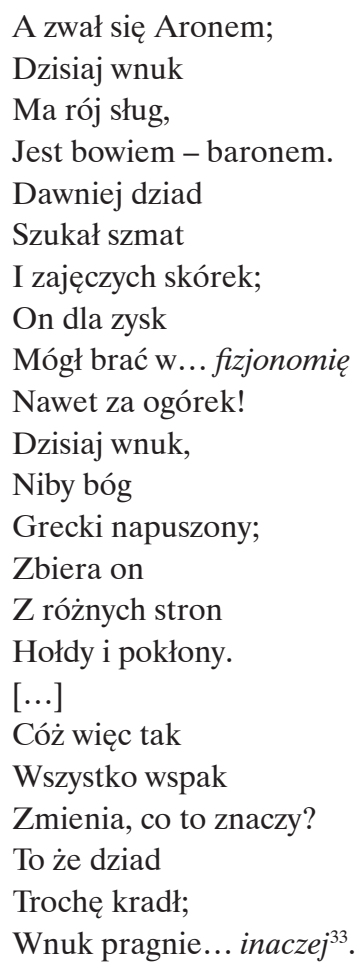

Owo zapisane kursywą ,inaczej” sugeruje dwuznaczność. W tym przypadku Jeleński nie zaufał intuicji swoich czytelników, co zazwyczaj czynił, i dokładnie wyjaśnił swój brak wiary w możliwość przeobrażenia Żydów w „Polaków wyznania mojżeszowego”, a także w ideały tak rozumianego postępu. Nie pominął też okazji do ataku na ideowych przeciwników nie tylko z kręgów pozytywistycznych, ale i konserwatywnych. Przedmiotem sporu było odmienne rozumienie kwestii żydowskiej, nie dość zdecydowane stanowisko organów konserwatywnych i ich rzekomy oportunizm w kontraście z hartem oraz nieustającą walką rolarzy ze złem jakoby ucieleśnionym w Żydach. „Rola” wielokrotnie podkreślała swoją niezawisłość, bezkompromisowość, odwagę w walce z Żydami wbrew szykanom, na które $\mathrm{z}$ tego powodu rzekomo była narażona. Jeleński jawił się w piśmie jako zwolennik prawdy, demaskator Żydów, których celem miało być jedynie czerpanie korzyści i dążenie do sukcesu oparte na krzywdzie Polaków. Atakował jednocześnie petersburski „Kraj” i „Prawdę”, swoim oponentom odpowiadając w ,poetyckim madrygale”:

${ }^{33}$ Kamienny, Na posterunku, „Rola” (1887), nr 37, s. 439. 
Wielką jest semicka moc,

Olbrzymią siła złota,

A więc dalej, w błocie - hoc!

Niech nas podziwia hołota!

Niech wie, co to jest prasa,

Gdy nią steruje żyd;

Wielka, potężna to rasa,

Tylko nie drażnić - psyt! ${ }^{34}$.

\section{Wzajemna „miłość”}

Grupą społeczną oskarżaną w „Roli” o ułatwianie Żydom asymilacji i integracji z Polakami była arystokracja, przeciwstawiona szlachcie uznawanej za wzór hermetyczności. Kosmopolityzm i wielkopańskość wymagająca kapitału były eksponowanymi cechami, które wraz z brakiem zasad, sprzedajnością i degeneracją przypisywano arystokratom. Posiadacze herbów wymieniający swe tytuły za pokaźny posag są przedmiotem krytyki w powieściach Antoniego Skrzyneckiego, Józefa Rogosza czy Jana Mieroszewicza [Wacława Gąsiorowskiego] ${ }^{35}$. Ten sam wątek pojawia się w prozie i poezji Autorki Opowiadañ ${ }^{36}$ oraz Nieznajomego, który w utworze o ironicznym tytule $Z$ miłości prezentuje bohaterkę utworu, pannę Ruchlę, która dobija targu z utracjuszem z książęcą mitrą:

Panicz spłonął gniewem trocha;

Panno Ruchlo - począł szydzić -

Któż się w takiej pannie kocha,

Która mówi: z herbiem - widżycz?

Nos, który burbońskim zwiecie,

I te, Maryi Stuart włosy,

Ta wiewiórcza szerść nad czołem

Protestują w niebogłosy! ${ }^{37}$.

W wierszu wyeksponowana jest karykaturalna, budząca odrazę cielesność wybranki hrabiego, a jej fizjonomia przypomina opis dziecka w opowiadaniu

${ }^{34}$ Kamienny, Na posterunku, „Rola” (1887), nr 36, s. 427.

35 Więcej na ten temat zob.: Domagalska, Zatrute ziarno..., s. 246-260.

${ }^{36}$ Mimo wysiłków nie udało się ustalić, kto ukrywa się pod tym pseudonimem.

${ }^{37}$ Nieznajomy, Z miłości, „Rola” (1892), nr 10, s. 150 (ortografia jak w oryginale). Według wskazówek zawartych w Ćwierćwieczu walki... (s. 102-103) pod tym pseudonimem ukrywał się Franciszek Reinstein, jednakże różnorodność stylistyczna utworów podpisanych w ten sposób może sugerować, że autorów było więcej. 
Dwa wspomnienia autorstwa Nieznanego. Potomek mieszanego małżeństwa, podobnie jak bohaterka wierszowanego obrazka, z woli autora obdarzony jest „burbońskim nosem” i włosami o barwie „kanałowego angielskiego szczura"38. Podobieństwo fraz zapewne nie jest przypadkowe, gdyż należy domniemywać, że twórcą obu tekstów jest ta sama osoba. Można więc przyjąć, że pisarze publikujący w „Roli” byli dostarczycielami wszelkiego rodzaju tekstów, zarówno publicystycznych, prozatorskich, jak i wierszowanej satyry. Ponadto powielali wątki z rolarskiej prozy i używali ich w skondensowanej postaci w poezji, eksponując zasadniczą kwestię.

Matrimonia mixta, zmiana pozycji społecznej oraz uzurpacja przypisywana Żydom są także tematem wiersza Autorki Opowiadań zatytułowanego Dawniej i teraz ${ }^{39}$, gdzie w formie lamentacji ukazana jest postępująca degrengolada dawnych hetmańskich rodów, których potomkowie poprzez małżeństwa z córkami bankierów ratują swoje majątki. W innym utworze, z roku 1897, o zdecydowanie satyrycznym charakterze, anonimowy autor kpi ze sprzedajnych hrabiów, gotowych oddać herb za pożyczkę na wyścigi. Wiersz ma formę dialogiczną między hrabią Golcem-Hołyszewskim a Szmulem Stockfishem. Starającemu się o rękę panny Róży hrabiemu Stockfish odpowiada:

My tu mieli dość fatygi,

To widocznie w te wyścigi

Narodowe takie święta!

Co dzień do nas przychodzili

Same hrabie i książęta,

Oglądali i gwarzyli...

Wielki wybór był na zięcia!

Tom ja wybrał sobie księcia ${ }^{40}$.

\section{Nowy dziedzic}

Także motyw nabywania majątków ziemskich przez Żydów, obecny w rolarskiej prozie, znajduje swoje odzwierciedlenie w poezji. Wątkiem przewodnim jest awans społeczny żydowskiej rodziny, która nabywa dobra

38 Nieznany, Dwa wspomnienia (Fantazja), „Rola” (1889), nr 26, s. 349.

${ }^{39}$ Autorka Opowiadań, Dawniej i teraz, „Rola” (1890), nr 28, s. 477. Wątek mieszanego małżeństwa, które jednak nie zostaje zawarte na skutek oporu szlachcianki Jadwigi Zapolskiej, pojawia się także w powieści Autorki Opowiadań, Von Kramst, publikowanej w „Roli” w latach 1888-1890.

${ }^{40}$ Bańki... ale nie mydlane, Korespondencja miłosno-sportowa $z$ „Kuriera Świątecznego”, „Rola” (1897), nr 20, s. 325. 
ziemskie, co piszący uważają za kuriozalny pomysł i ośmieszają go na różne sposoby. Nieznajomość form obyczajowych świata ziemiańskiego, skąpstwo kolidujące ze szlachecką tradycją, brak wyczucia rytmu pór roku i wykonywanie niezgodnych z nimi czynności, nieumiejętność jazdy konnej czy polowania to tylko niektóre z ośmieszanych cech przypisywanych Żydom. Do nich dochodzi także czynnik zagrożenia - wycinanie lasów, wyjałowienie gruntów, rabunkowa gospodarka rolna. W wierszu Nowy dziedzic, podpisanym przez Antoniego Orłowskiego, przeważa ta druga opcja:

Nad strumykiem, ponad białym

Leżą drzewa masy.

Ech, to Boruch, nowy dziedzic,

Wyrąbuje lasy ${ }^{41}$.

W podobnej konwencji, utrzymany w tonie skargi polskich włościan, napisany jest wiersz Po kolędzie, który zamieszczono w pierwszym numerze z 1890 r. Teza utworu znakomicie wpisuje się w tytuł wielokrotnie wznawianej broszury Jeleńskiego $\dot{Z} y d z i$, Niemcy i my, a także w artykuł programowy Czego chcemy otwierający pierwszy numer „Roli”. Sentymentalny ton przyjęty przez Autorkę Opowiadań kształtuje wizerunek chłopów jako nośników polskiej tradycji i wiary, a także ludzi stawiających opór obcym - Niemcom i Żydom:

Boże Narodzenie Jedynego Syna,

Próżno niemiec z żydem sieć łowczą rozpina.

Próżno! - nasze ziemie -

Na nich słowian plemię -

Nie dla niemca i żyda ${ }^{42}$.

W innym utworze, ironicznie zatytułowanym Miłość bratnia, Autorka Opowiadań, wzorując się na dialogicznej konwencji Pijaństwa Ignacego Krasickiego, ustami jednego z bohaterów wylicza klęski, które z powodu Żydów spadły na okoliczną szlachtę. W deskrypcji włożonej w wypowiedź szlachcica Żydzi poddani są animalizacji, przypisane są im atrybuty pasożytniczych i drapieżnych stworzeń, pojawia się również charakterystyczna dla antysemickiego dyskursu metaforyka choroby:

${ }^{41}$ Antoni Orłowski, Nowy dziedzic, „Rola” (1890), nr 10, s. 150. Podobna teza widoczna jest w satyrze Pawła Kośmińskiego, Pan Zalzman rolnikiem (sylwetka z natury), „Rola” (1891), nr 6, s. 81.

42 Autorka Opowiadań, Po kolędzie, „Rola” (1890), nr 1, s. 6. 
Może jaki ratunek? I cóż to za klęska?

Żydzi? - Jak to, co żydzi. - No mówię ci: żydzi

Cholera - morbus świata, pijawki, Bóg widzi,

Krety i grzechotniki, drapieżnicy, zdzierce

Wampiry merkantylne, wpiją ci się w serce.

Wyssą ostatnie soki z każdej twojej żyły;

$\mathrm{W}$ ich to szpony, pazury losy mnie wtrąciły ${ }^{43}$.

Zgodnie z konwencją satyry mądry po szkodzie szlachcic udziela pouczenia innym, korespondującego zresztą z ideologicznym założeniem „Roli”. Jest ono zgodne z propagowaną w piśmie koncepcją asemityzmu księdza Mariana Morawskiego, a także $\mathrm{z}$ hasłem przewodnim Jeleńskiego: „Chleb dla swoich”44. W domyśle pojawia się nakaz zakładania kas zapomogowych, zarówno szlacheckich, jak i włościańskich, wpisujący się w koncepcję „małej polityki” propagowanej w „Roli”, która wykluczałaby Żydów jako pożyczkodawców:

Gdyby szedł, jak jeden mąż, zgodnie kraj nasz cały,

Semickie te fortele nic by nie wskórały.

Nie wpuszczać $w$ nasze progi semity faktora,

Do handlu z żydem szlachta niech nie będzie skora,

Dajmy przykład włościanom, ratujmy się w nędzy,

Poprzestańmy na małym, bez Żyda pieniędzy ${ }^{45}$.

Podobnie jednak jak w satyrze Krasickiego interlokutor szlachcica, wysłuchawszy mowy i samokrytyki sąsiada, będąc w finansowej potrzebie, pobiegł zastawić swoje srebra, a córkę wydał za Goldwassera. Tym samym wynikające z utworu pouczenie brzmi: Polacy sami działają na swoją zgubę.

W satyrze, jak też i w prozie Autorki Opowiadań, nie tylko zarysowuje się nowoczesne antysemickie imaginarium widoczne w animalizacji czy metaforyce choroby, lecz także pojawia się kategoria rasy, jednoznacznie określająca nieprzekraczalną barierę krwi. Nic tu nie mają do rzeczy katolickie deklaracje Jeleńskiego, który również w przypadku konwertytów, przyjmowanych przecież na łono Kościoła, zachowywał daleko

${ }^{43}$ Autorka Opowiadań, Miłość bratnia (satyra), „Rola” (1890), nr 36, s. 601.

${ }_{44} \mathrm{Na}$ temat asemityzmu i reakcji na koncepcję księdza Morawskiego w prasie polskiej aż do 1939 r. zob.: Szymon Rudnicki, Asemityzm, [w:] tenże, Równi, ale niezupetnie, Warszawa 2008, s. 64-77; Krzysztof Lewalski, Kościoły chrześcijańskie w Królestwie Polskim wobec Żydów w latach 1855-1915, Wrocław 2002, s. 125-126; Marcin Soboń, Polacy wobec Żydów w Galicji doby autonomicznej w latach 1868-1914, Kraków 2011, s. 99-101.

45 Autorka Opowiadań, Miłość bratnia..., s. 601. 
idącą powściągliwość. Bliższa jest więc Jeleńskiemu, a także innym współpracownikom „Roli”, optyka poetycko ujęta przez Autorkę Opowiadań:

Natura daje ludziom pewne formy ciała

By odcisnąć ras cechę - cecha ta jest stała.

Nie była też sokołem żadna dotąd sowa

Choć to i to ród ptasi, klasa jednakowa.

Zlawszy żyda z polakiem, toć to co od żyda

W dziesiątym pokoleniu jeszcze ferment wyda ${ }^{46}$.

\section{Komu tutaj mydlić oczy?}

W poezji, jak w prozie, pojawiają się więc wątki dominujące w rolarskiej publicystyce. Poezja - przyjmująca formułę obrazków, gawęd, satyr - utrwala negatywne stereotypy, wyśmiewa Żydów, ukazuje ich w karykaturalnej postaci. W przypadku wierszowanej gawędy Wdzięczny Szmul tematyka wiersza powtarza niemal dokładnie fabułę opowiadania $C z y$ to we krwi płynie, opublikowanego w „Roli” w roku 1883, mówiącego o szkolnej przyjaźni Władysława S-kiego z Żydem, którego prześladują szkolni koledzy, a szlachcic staje w jego obronie ${ }^{47}$. Fabuła dowodzi, że przyjaźn Polaka z rzekomo zasymilowanym Żydem jest niemożliwa. Ostatecznie zawsze okaże się, że pochodzenie, a tym bardziej krew, jest silniejsze w zderzeniu z kulturą, więc akulturacja będzie jedynie pozorna ${ }^{48}$. Podobnie Ostatni Żyd w Warszawie. Utopia rymowana jest powieleniem tematu widocznego w opowiadaniu Monolog i Sen Dawida w noc sylwestrowa. Jej bohater wraca z Ameryki, w której trzeba ciężko pracować, do prawdziwej ziemi obiecanej, czyli Warszawy. Utrzymana w konwencji onirycznej opowieść również ośmiesza syjonizm i emigrację Żydów, którzy nie są w stanie zbudować podstaw państwowości ani zróżnicowanego gospodarczo społeczeństwa. W epilogu bohater, otrząsając się z koszmarnego snu, stwierdza:

Bo ten cały Syjonizm, to kiepski interes.

Kto go pierwszy wymyślił, jest wariat i kwita,

Albo może, co pewniej, to... antysemita.

Wszyscy w kółko mówicie: „Ziemia obiecana”.

Mamy ją pod nogami: Warszawa kochana.

Nas tu jest duża chmara, ze trzysta tysięcy.

46 Tamże, s. 602.

${ }^{47}$ Korab, Czy to we krwi plynie? Obrazek ze wspomnień..., „Rola” (1883), nr 27-34.

48 Szablic, Gawędy. Wdzięczny Szmul, „Rola” (1897), nr 2, s. 22. 
My się prędko mnożymy. Za rok będzie więcej.

Chcecie wiedzieć, gdzie Syjon? Spytajcie się Ryfki.

Ona zaraz odpowie: To nasze Nalewki ${ }^{49}$.

Podobna teza pojawia się w wierszu zamieszczonym w rubryce Bańki, ale nie mydlane, w którym bohater - Czech przybywający do Warszawy - dokonuje jej oceny z perspektywy turysty zadziwionego specyfiką miasta. Zabieg wprowadzenia narratora oceniającego warszawskie realia pozwala na zdystansowanie się autora i zachowanie pozorów bezstronności, wzmacnia tym samym kreowany wizerunek Warszawy jako miasta zdominowanego przez Żydów, gdzie Polacy jedynie pozornie są gospodarzami. W wierszu słychać zapewne reminiscencje wyborów do Dumy, w które „Rola” angażowała się za każdym razem po stronie bloku narodowego i obawiała się wpływu głosów wyborców żydowskich z przeciwnej strony politycznej na ich ostateczny wynik. Peregrynujący po stolicy bohater:

Obszedł sklepy, zwiedził banki,

Handlu i przemysłu szranki,

I stąd wysnuł sąd ciekawy,

Że Żyd panem jest Warszawy ${ }^{50}$.

Podobny zabieg wprowadzenia zewnętrznego obserwatora zastosowany zostaje w wierszu opublikowanym w roku 1895, gdzie w charakterze etnografa występuje Anglik. W utworze wykorzystany jest konglomerat antysemickich skojarzeń, począwszy od sfery doznań zmysłowych - rzekomo charakterystycznej woni znanej w antysemickim piśmiennictwie jako „foetor judaicus” ${ }^{\text {, }}$, po przypisywane Żydom: brud, nadmierną ekspresję, posługiwanie się „szwargotem”, wywołujące poczucie wyższości mówiącego wobec całkowicie odrębnych i odrażających dla niego Innych:

Bezustanny szwargot słyszał

I harmider wniebogłosy...

I w Otwocku, w Mokotowie

Jakiś także świat odrębny,

Zasmolone, zabłocone

Kędzierzawe krążą bębny...

Zewsząd czuć coś... prawie odór,

${ }^{49}$ Marzyciel, Ostatni Żyd w Warszawie. Utopia rymowana, „Rola” (1899), nr 32, s. 524.

50 Jan B., Czech w Warszawie, „Rola” (1909), nr 33, s. 511.

${ }^{51}$ Piotr Weiser, „Po przekroczeniu tego progu zaczyna się królestwo śmiechu...”. Antysemityzm jako wywachiwanie, „Teksty Drugie” (2011), nr 3, s. 253-261. 
Co wszelaki nos nieczuli,

A nad wszystkim się unosi

Obrzydliwa woń cebuli ${ }^{52}$.

W publicystyce i poezji potencjalna emigracja Żydów - zarówno do Palestyny, jak i do kolonii barona Hirscha w Argentynie - traktowana jest sceptycznie $^{53}$. Kolonie argentyńskie są przedmiotem satyry Nie-Judofila ${ }^{54}$, a kwestię syjonizmu podsumowuje Nieznajomy w wierszu o znaczącym tytule Komu tutaj mydlić oczy. Konkluzja jest oczywista - syjonizm to jedynie fikcja, gra pozorów. W rzeczywistości pozostaje jedynie dotychczasowa czujność wykazywana przez „Rolę”. Jak poucza Nieznajomy:

A więc bracia, uszy w górę!

Czujność, bystrość i uwaga:

Przekonacie się, iż wkrótce

Ta „wychodźcza” pęknie blaga ${ }^{55}$.

\section{Podsumowanie}

Poezja w „Roli”, a raczej wierszowana satyra, korespondowała więc z publicystyką i powieścią, choć nie była domeną pisma. Wierszowanych form - zazwyczaj podniosłych w nastroju wierszy o treści religijnej bądź antyżydowskich utworów satyrycznych - było raczej niewiele. Można przyjąć, że utwory poetyckie dostarczali autorzy, którzy na łamach „Roli” drukowali powieści o tendencyjnym charakterze. To w nich rozwijali wątki korespondujące z publicystyką pisma, nadając im fabularny charakter i wpisując tendencję w intrygującą fabułę. Niewątpliwie głównym dostarczycielem wierszowanych utworów był Paweł Kośmiński, podobnie jak Antoni Skrzynecki - autor powieści drukowanych w odcinkach. Po śmierci Kośmińskiego w 1896 r. widoczna jest przerwa, a form wierszowanych jest niedużo. Pojawiają się później, lecz w bardzo ograniczonym zakresie, w rubryce Bańki, ale nie mydlane.

52 P.K., Dziwny naród, „Rola” (1895), nr 32, s. 537.

${ }^{53}$ Więcej na temat postrzegania syjonizmu w „Roli” zob.: Agnieszka Friedrich, „Rola” wobec syjonizmu, „Kwartalnik Historii Żydów” (2016), nr 2, s. 451-473.

${ }^{54} \mathrm{O}$ cyklu wierszy satyrycznych Nie-Judofila (Pawła Kośmińskiego) pisałam w artykule „W państwie Hirsza - w Argentynie...”. Satyryczny obraz emigracji Żydów do Ameryki Południowej na łamach „Roli”, [w:] Żydzi i judaizm..., s. 183-195.

55 Nieznajomy, Komu tutaj mydlić oczy, „Rola” (1902), nr 40, s. 633. 
U progu dwudziestego stulecia „Rola” zamieszcza wiersz zatytułowany Nie tak to bracie drzewiej bywało:

Nie daj Boże, by semita

Miał nas uczyć moralności!

Choć niejeden wiem, że spyta:

Cóż w tym złego dla ludzkości?

Wszak żydowie są dziś pono

Ludźmi często wybitnymi,

$\mathrm{Z}$ duszą wzniosłą, ukształconą,

$\mathrm{Z}$ dążeniami szlachetnymi...

Być to może, cni Panowie,

Że to wszystko ma semita,

Że i gada „postępowie”,

Lecz żyd-żydem... ot i kwita ${ }^{56}$.

Konkluzja tego wiersza podsumowuje tendencje panujące w piśmie, które od zarania tzw. kwestię żydowską postawiło w centrum swej uwagi - w publicystyce, prozie, a nawet w mowie wiązanej. Bez wątpienia wierszowane teksty w „Roli” trudno uznać za poezję wysoką. Była to raczej satyra wspomagająca publicystykę i w lekkiej, choć zjadliwej formie komentująca nurtujące rolarzy sprawy. Nie wnosiła ona nic nowego w zakresie dominujących wątków, była raczej ich uzupełnieniem. W syntetycznej formie wzmacniała antysemicki przekaz, podkreślając powiedziane już wielokrotnie kwestie. O jej podrzędnym znaczeniu świadczy także to, że większość tekstów zamieszczonych jest anonimowo lub pod trudnymi do deszyfracji pseudonimami. Bywają one jednak znaczące jak w przypadku Nie-Judofila, czyli Pawła Kośmińskiego, który jako jedyny obdarzony był satyrycznym talentem, niestety wprzęgniętym w służbę tendencji. Natomiast w większości utworów prozatorskich możliwe jest rozszyfrowanie autora, nawet jeśli nie publikował pod swoim prawdziwym nazwiskiem. Można przyjąć, że lekkie, z założenia ośmieszające teksty utrwalały antysemicki przekaz, eksponując jego zasadniczą dominantę. Jak zauważa Agnieszka Jagodzińska, analizując wizerunek Żydów w twórczości misyjnej, poezja „przez swą zwięzłą i krótką formę zmuszała do precyzyjnego rysowania obrazu. Mowa wiązana utrwalała go ponadto w pamięci o wiele sprawniej, niż mogła to zrobić proza” ${ }^{57}$. W „Roli” przedmiotem szyderstwa byli przede wszystkim

56 J. Wyszyński, Nie tak to bracie drzewiej bywało. Gawęda, „Rola” (1899), nr 44, s. 716.

57 Agnieszka Jagodzińska, „Szczególny lud”. Obraz Żydów w poezji misyjnej, [w:] taż, „Duszozbawcy”? Misje i literatura Londyńskiego Towarzystwa Krzewienia Chrześcijaństwa wśród Żydów w latach 1809-1939, Kraków 2017, s. 208. 
asymilujący się i bogacący się Żydzi, których uznawano za zagrożenie dla polskiego stanu posiadania podważające pozycję grupy dominującej. W paszkwilanckim tonie ośmieszano burżuazję pochodzenia żydowskiego, ostrzegano przed złowrogą działalnością Żydów w życiu gospodarczym, społecznym i politycznym kraju u progu XX stulecia. Atakowano też arystokrację i zawieranie małżeństw mieszanych, choć zjawisko to było w zasadzie marginalne. Stanowiło jednak novum, a budziło zainteresowanie ze względu na małżonków z możnych i wpływowych rodów.

Przez wszystkie lata swego istnienia „Rola” skupiona była przede wszystkim na analizowaniu kwestii żydowskiej w jednostronnej, antysemickiej optyce. Nie inaczej jest w poezji. Można więc przyjąć, że nieustający alert: Baczność. Wilk się zbliża, zawarty w wierszu opublikowanym w gorącym rewolucyjnym 1905 roku, był z jednej strony podsumowaniem dotychczasowej linii programowej pisma, z drugiej zaś wyznaczał wciąż ten sam kierunek w końcowych latach funkcjonowania „Roli”58.

\section{Bibliografia}

\section{1. Źródła opublikowane}

Ćwierćwiecze walki. Księga pamiątkowa „Roli”, Warszawa 1910.

Jeske-Choiński Teodor, Poznaj Żyda, wyd. 3, Warszawa 1912.

„Rola” 1883-1912.

\section{Opracowania}

Domagalska Małgorzata, Zatrute ziarno. Proza antysemicka na łamach „Roli” (1883-1912), Warszawa 2015.

Eisenbach Artur, Emancypacja Żydów na ziemiach polskich 1785-1870 na tle europejskim, Warszawa 1988.

Eisenbach Artur, Memoriał w sprawie sytuacji Żydów w Królestwie Polskim, „Biuletyn Historii Żydów Polskich" (1976), nr 4.

Friedrich Agnieszka, The Image of a Wealthy Jewish Family in the Anti-semitic Polish Weekly “Rola”, „Scripta Judaica Cracoviensia” (2015), nr 13.

Friedrich Agnieszka, „Rola” wobec syjonizmu, „Kwartalnik Historii Żydów” (2016), nr 2.

Jagodzińska Agnieszka, „Duszozbawcy”? Misje i literatura Londyńskiego Towarzystwa Krzewienia Chrześcijaństwa wśród Żydów w latach 1809-1939, Kraków 2017. Janion Maria, Bohater, spisek, śmierć. Wykłady żydowskie, Warszawa 2009.

${ }^{58}$ Nie-Ezop, Bańki, ale nie mydlane. Z chwili, „Rola” (1905), nr 38, s. 589. 
Kołodziejska Zuzanna, „Izraelita”(1866-1915). Znaczenie kulturowe i literackie czasopisma, Kraków 2014.

Krzywiec Grzegorz, Polska bez Żydów. Studia z dziejów idei, wyobrażeń i praktyk antysemickich na ziemiach polskich początku XX wieku (1905-1914), Warszawa 2017.

Lewalski Krzysztof, Kościoły chrześcijańskie w Królestwie Polskim wobec Żydów w latach 1855-1915, Wrocław 2002.

Moszyński Maciej, Antysemityzm w Królestwie Polskim. Narodziny nowoczesnej ideologii antyżydowskiej (1864-1914), Poznań 2017.

Pąkciński Marek, Konserwatyzm na rozdrożu. „Młodzi konserwatyści” warszawscy wobec ideowych dylematów schyłku XIX wieku, Warszawa 1994.

Rudnicki Szymon, Równi, ale niezupetnie, Warszawa 2008.

Sierotwiński Stanisław, Kośmiński Pawet, [w:] Polski Słownik Biograficzny, t. 14, Wrocław 1968.

Soboń Marcin, Polacy wobec Żydów w Galicji doby autonomicznej w latach 18681914, Kraków 2011.

Śliwa Michał, Obcy czy swoi. Z dziejów poglądów na kwestię żydowska w Polsce w XIX i XX wieku, Kraków 1997.

Weeks Theodore R., From Assimilation to Antisemitism: The "Jewish Question" in Poland 1850-1914, DeKalb 2006.

Weeks Theodore R., The "International Jewish Conspiracy” Reaches Poland: Teodor Jeske-Choiński and His Works, „East European Quarterly” 31 (1997), nr 1.

Weiser Piotr, „Po przekroczeniu tego progu zaczyna się królestwo śmiechu...”. Antysemityzm jako wywachiwanie, „Teksty Drugie” (2011), nr 3.

Zawialska Maria, „Świt” Marii Konopnickiej. Zarys monograficzny tygodnika dla kobiet, Wrocław 1978.

Żydzi i judaizm we współczesnych badaniach polskich, t. 6, red. Stefan Gąsiorowski, Magdalena Ruta, Kraków 2017.

Małgorzata Domagalska

Uniwersytet Łódzki

malgorzata.domagalska@uni.lodz.pl 